\title{
Factors Affecting Fresh Graduate Bankruptcy at Young Age: The Case of Fresh Graduates in Kota Damansara
}

\author{
Uma Murthy $^{1} \&$ Paul Anthony Mariadas ${ }^{2}$ \\ ${ }^{1}$ Global Leadership Research Unit, Malaysia \\ ${ }^{2}$ Faculty of Business, Accountancy and Management, SEGi University, Malaysia \\ Correspondence: Uma Murthy, Global Leadership Research Unit, Malaysia. E-mail: umamurthy@segi.edu.my
}

Received: February 10, 2017

Accepted: November 10, 2017

Online Published: November 20, 2017

doi:10.5539/ijbm.v12n12p194

URL: https://doi.org/10.5539/ijbm.v12n12p194

\begin{abstract}
The paper studies the relationship between factors affect fresh graduate bankruptcy at young age and with credit card, bank policies, poor financial planning and attitude towards money. This study has also employed the multiple regression method to examine the studies to test the relationship and to test the hypothesis. Furthermore, the data was analyzed with the software known as Statistical package for Social Science, for short SPSS using 130 questionnaire. The results show indication that there is positive relationship between fresh graduate bankruptcy with credit card, bank policies, poor financial planning and attitude towards money.
\end{abstract}

Keywords: factors, fresh graduate bankruptcy, young age

\section{Introduction}

Fresh graduate bankruptcy became part of common issues among generation Y, and bankruptcy has become an obstacle among fresh graduate from advancing in terms of careers. The increase of fresh graduate bankruptcy is mostly affected fresh graduate that are born mid 1990's to early 2000's. These issues usually affect fresh graduate who are living in developed countries either living in the cities. Before that, fresh graduate bankruptcy issue hasn't been noticed until there are amount of students unable to pay back their student loan that are issued by Malaysia.

The objective of this research is to study and review the factors that causing fresh graduate bankruptcy by identifying what are factors that influencing the bankruptcy such as poor financial planning, over spending using credit card, bank policies, and attitude towards money.

Spending has now increase compared to the last generation because the existence of "Credit cards". Nowadays, society are now going cashless in buying and utilize credit cards as "plastic" money as a form of purchasing and soon going to replace the traditional form of cash money purchases (Soman, 2003). Furthermore, credit cards are now regarded as a spending stimulus that causes more spending than the usual cash (Cui, 2014). Further studies concluded that there is evidence that the usage of credit card has encourage spending which cause credit card holders to underestimate the price of products and neglected the amount has spent during the purchasing activities, where soon lead to problem of overuse (Durkin, 2000).

Bank policies is one of the factors that will contribute to fresh graduates bankruptcy at young age, furthermore, bank policies are the one in charge with the adjustment of credit card benefits, the repayment policies and the minimum qualification required for a credit card (Chong, 2013). Due to the perfect competition in the credit card industries, many banks are striving in establishing their own perfect credit card plan through making constant improvement and innovation towards credit card (Subramanian, 2010). Other than that, many credit card issuing banks are offering benefits and different form of incentives in order to lure more customers in registering for credit card (Chakravorti, 2013).

Attitude towards moneys is another major factor that leads to fresh graduates' bankruptcy. (Robert, 2001) stated that where attitude change can lead to behavioral changes. Thus, the attitude towards money will actually affect fresh graduates spending behaviour. According to the explanation of (Woo, 2008) they defined that the attitude towards money can have a huge impact on a person life that includes the person saving habit, spending behaviour, performances in the workplace, ideology in politics and attitude towards environment. 
Poor financial Planning is part of the important factor which concerns fresh graduates' bankruptcy. According to (Maniam, 2002) many college student has no regards for their own financial status, the plan for their future wealth when reach certain age and most importantly retirement planning. When students graduate from college, they reflect the attitudes of the general population in that their main concerns are finding and holding jobs, which means that the general population including the rest of the households has no intention of creating a financial plan at all (Joe James, 2002).

This research is showed by the subsequent questions; (1) What is the relationship between credit card spending and fresh graduate's bankruptcy in Malaysian context? (2) What is the relationship between bank policies and fresh graduate's bankruptcy in the Malaysian context? (3) What is the relationship between attitude towards money and fresh graduate's bankruptcy in the Malaysian context? And finally (4) what is the relationship between financial planning and fresh graduate's bankruptcy in the Malaysian context?

To seek the answers to these questions, this research will be organized into five (5) sections. Section one captures the introduction, section two discusses review of updated literatures, section three (3) highlights the methodology employed in analyzing empirical data for this research, section four (4) discusses data collection and analysis whilst, section five (5) provides the conclusion and recommendations, as well as the contributions and limitations of the research.

\section{Literature Review}

\subsection{The Definition of Fresh Graduates}

In this research, fresh graduates is defined as an individual have borrowed heavily for education, or some particular things they desire to purchase without any thought of the product necessary and yet purchased with regards with the price of product and leaving themselves with deeply in debt (Austin, 2013).

According to (Ludlum, 2012) Financial literacy became part of the bankruptcy issue where arises from fresh graduate does not have adequate knowledge about credit card usage especially the terms of their credit card, results that the banks made profit out of consumer mistake. For example, fresh graduate does not acknowledge the current interest rate he or she is paying, fresh graduate does not know they are late payment charges for credit card and most of the fresh graduate does not know the penalty for over being over credit balance (Seyedian, 2013). Moore (2013) states that fresh graduate are ought to have minimal financial knowledge in order to finance their expenses. Moore (2013) suggested that financial education and counseling must take places before fresh graduate has deeply in debt and unable to meet financial obligations.

Furthermore, collage loans and tuition fees became part of the inevitable debt which affect fresh graduate wanted to further their studies in college or university despite household has low level of income, which results in bankruptcy. According to the same source stated that the term "Materialism" mentality has influence fresh graduate society, where fresh graduate has more desire in wealth and expensive branded goods that will leads to risky financial behavior, part of this contributes to fresh graduate's crisis (Segev, 2015).

Possession of credit card is one of the causes that fresh graduates is in debt, especially teenage that lies fresh-graduate level has low level of income, worst part is when fresh graduate has insufficient knowledge towards financial literacy according to (Yong, 2013). External factors that cause bankruptcy is Bank Policies, according to (Yong, 2013) due to competition in the credit card industry, bank constantly make product improvement by providing various incentive such as no annual fees, cash rebates, point redemption, installment plan for branded goods or having discount on daily necessities product, these cause fresh graduate has more desire for applying credit card. Thus, this aggressive marketing made by credit card industry causing fresh graduate has more buying power regardless of low level of income which leads to fresh graduates (Seyedian, 2013).

\subsection{Credit Card Spending}

Spending has now increase compared to the last generation because the existence of "Credit cards". Nowadays, society are now going cashless in buying and utilize credit cards as "plastic" money as a form of purchasing and soon going to replace the traditional form of cash money purchases (Soman, 2003).

In this study, three demographic factors can be considered influencing credit card holder spending behavior which is age, income level, and occupation. According to (Devlin el al, 2007) found that the older respondent of this research are more likely to possess one or more credit cards. College students or fresh graduates are the one who possess only fewer credit cards, in this case this group of people have been identified as the contributors to credit card debts compared to older age that possess credit card (Maria, 2002). 
According to (Sepulveda, 2009), the reason why young credit card holders contribute more to credit card debt is because in their perception, they believe that the burden of financial obligation will not face by them because they still have a long future ahead for them to settle the debts. However, (Yong, 2013) stated that any financial problem that will faced by young credit card holders will be temporary and furthermore will be easily repaid due to their young age, based on the assumption of young credit card holders.

According to (Devlin et al, 2007), the amount of credit card possession per household are reflected by the income level of the household respectively. In this case, credit card issuing bank banks will start developing alternative ways of creating more new credit card holders and furthermore increasing the number of credit card of each holder possess and this involve among middle level income and lower level income sections by reducing the minimum requirement of total annual income per person. Based on the example stated by (Loke, 2010), during in the 1900s to mid-2000s, the minimum requirement of RM 18,000 (USD 5,881) per annum income is required for applicants to apply a basic credit card, and for a normal credit card requires RM 24,000 (USD 7,842) per annum income. Basically, any applicants who have an annual income of RM 18,000 are already entitled for a credit card today.

According to Joo (2002), a person spending and consumption behavior can be reflected by the occupation of the person. Pauwels (2002) studies that managers and self-employed credit card holders are tend to spend and consume more by using credit card. With more Malaysian with different occupations, including student that has been categorized as an occupation is now started to own credit cards and soon it will become a common trend in near future (Teoh, 2013).

\subsection{Bank Policies}

Bank policies is one of the factors that will contribute to fresh graduates bankruptcy at young age, furthermore, bank policies are the one in charge with the adjustment of credit card benefits, the repayment policies and the minimum qualification required for a credit card (Chong, 2013).

Nowadays, in order for credit card industries to sustain in the perfect competition, card issuing bank company will offer different incentive and benefits that will attract more customers (Marimuthu, 2010). Incentives such as annual fees waiver where normal credit card are required to pay annual fees every year and the amount of annual depend on the type of credit card possessed. Cash Rebates, every credit card holds different type of cash rebate where it can get cash rebates when consumer made purchasing in the specific shopping outlet. Point rewards, this is one of the common tactics promoted by most of card issuing bank to encourage consumer to purchase more with credit card to gain point rewards and later exchange for better goods. Airline miles, works similarly with point rewards but it only works on airline company for example, frequently business traveller can collect airline miles and later can use collected miles to redeem free flight tickets, this is the loyalty program often offer by airline company (Chong, 2013). (Yong, 2013) also stated that these are the relationship marketing from card issuing bank company that cause the desire of consumer to spend more on credit card. (Hamsawi, 2012) from the Nielson Global Survey of Investment Attitudes reported that two in five or 39 percent of Malaysian use credit card as a common payment such as for dinning, shopping, and entertainment activities.

Furthermore, qualification of owning a credit card plays in the big part in fresh graduates' bankruptcy because there is some requirement that has been eliminated due to the marketing model, qualification such as require the copy of credit card applicants identification cards, salary slips, income tax and any other important document that can be a proof to identities (Teoh, 2013).

Other than that, credit card issuing card also provide attractive repayment policies where if customer able to pay back the debt in the grace period of time, there will be no interest charged (Lee, 2012). Otherwise, if late payment has been made in purchases there will be charge a fixed minimum of RM 10 or 1 percent of total outstanding balance of the purchase (Hamsawi, 2012). Akin (2008) stated that nowadays, many card issuing banks allow a minimum amount to be paid in their quest towards transforming consumers into interest-paying consumer by providing different incentives.

\subsection{Financial Planning}

According to Hastings (2012) having financial planning means that the ability to utilize one's knowledge and personal skills to manage personal finance resources effectively. Having effective mathematical skills is mandatory to financial decision making and can be beneficial as well.

Several studies concluded that if credit card were financially planned before utilized, this mechanism can provide better financial security, in many cases its best used for emergency purpose, however if credit card were misuse it can cause financial risk (Perito, 2014). Student without financial planning are ought to suffer financial 
stress because having financial stress is the inability to achieve an individual economics responsibilities and can be influenced by attitude, beliefs and other psychological factors as stated by (Tibbetts, 2015). According to (Lim 2014), student without financial planning are more likely to have financial stress and more of them seek professional financial counseling for financial planning purpose.

Another factor to affect poor financial planning is financial behavior. Stutz (2015) defined that positive and healthy financial behaviors are the indicators of any young adults to achieve financial, economic and personal goals that are important to them. Fernatt (2015) also stated that Good financial behavior are more prompt to having better financial planning because they are aware of how much of debt owned, learn to check the lowest interest rate before decide on borrowings, have monthly or weekly saving, conduct personal financial budgeting and keep track of financial goals. Furthermore, college students that are better financial behavior are more satisfied with their personal financial situations (Canale, 2015).

Lack of investment decision, serve as a factor to poor financial planning. According to Joyce (2013) some Malaysian invest their savings in low interest yielding banking accounts which is not sufficient for future needs and furthermore the current economic condition and escalating of cost of living. According to further studies by (Joyce, 2013) 65 Per cent of 346 generation Y Malaysian respondent are relying on their own personal investment and savings to fund their future retirement. Yien (2013) stated that with the current results of respondent, suggested that active financial planning is necessary for generation Y Malaysians, unable to make better financial decision may hinder social welfare of individual or families.

\subsection{Attitude towards Money}

Attitude towards moneys is another major factor that leads to fresh graduate's bankruptcy. (Robert, 2001) stated that where attitude change can lead to behavioural changes. Thus, the attitude towards money will actually affect fresh graduates spending behaviour.

The aim of this section is to study the three dimensions of attitude towards money. The three dimensions are the willingness of credit card holders pay their credit card expenditure in time, credit card holder's awareness of the current interest rate and total debt owned in credit card and the credit card holder's management issues such as the income and finance expenses. According to (Durkin, 2000), there is doubt that whether fresh graduates has the understanding of the credit card cost and the implications of using the credit card. However, (Burns, 2005) explain that compulsive buying behavior are considered related to with the credit card usage. Because according to (Hoyer, 2001) fresh graduates that has terrible spending behavior tend to have no idea about how much money they had spent on item that are not needed and most of the item purchased are not affordable.

According to (Zafar, 2010), the Malaysian government has making many efforts to increase consumer spending where results can leads to rising in GDP growth, however the increase of domestic spending has also reduce the employee monthly contribution to employee provident fund by 2 per cent in year 2009. In this case, the annual fee for credit card has removed due to the government implementation and also indicating that the government has encouraged the use of credit card.

Alias (2010) stated that Malaysian are known as big spenders, and there are many Malaysian have continue to spend rigorously even though the price of goods and service has drastically increase for the past few years. In this case, according to (Hamsawi, 2012) there are only 47 per cent of Malaysian founded that actually pay credit card debt in full and in time and furthermore many Malaysian choose to trust their own instinct rather than relying on financial advisors and financial planners, most importantly when it comes with making decision in terms of financial decisions or managing wealth matters.

\subsection{Proposed Framework}

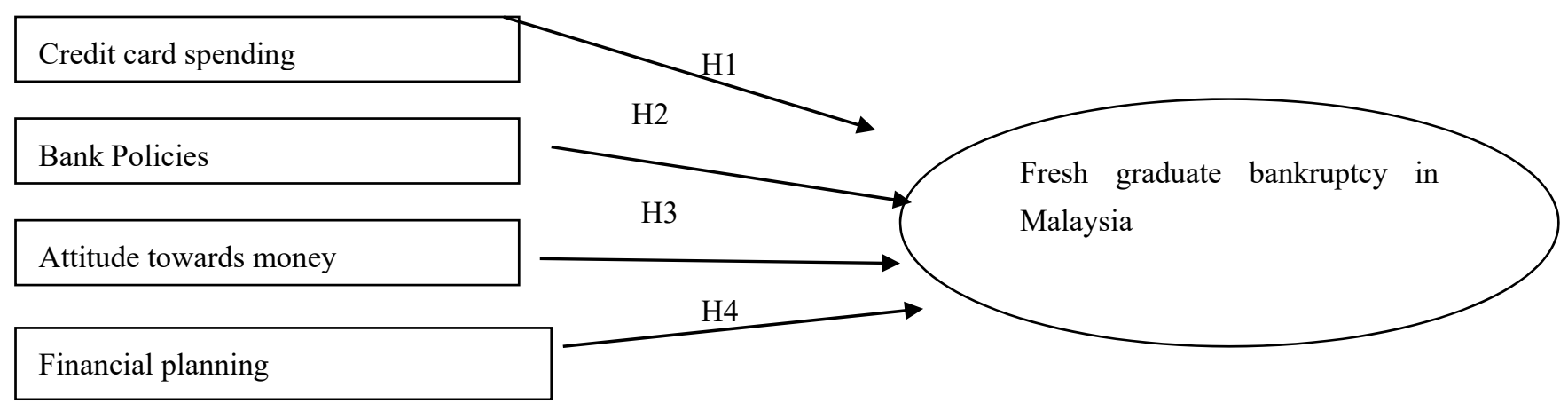




\subsection{Research Hypotheses}

H1: Credit card spending will have a direct significant affecting fresh graduate bankruptcy in Malaysia.

$\mathrm{H} 2$ : Bank policies will have a direct significant affecting fresh graduate bankruptcy in Malaysia.

H3: Attitude towards money will have a direct significant affecting fresh graduate bankruptcy in Malaysia.

H4: Financial planning will have a direct significant affecting fresh graduate bankruptcy in Malaysia.

\section{Research Methodology}

\subsection{Measurement and Collection of Data}

A quantitative research approach is employed in this research following the positivist assumption with a realist ontology and objectivist epistemology. Data was collected using a face to face interviews, various questionnaires and conclude observations with questionnaires as the main method of collecting data. The adapted survey questionnaire employed in this study is divided into two sections; demography and scales of the four (5) underlying factors of the research instrument, capturing four (4) independent variables and 1 dependent variables. A 5-point Likert scale was used showing (1) "strongly disagree", (2) "disagree", (3) "slightly agree", (4) "agree", (5) "strongly agree". The cronbach alphas of all 20 items in the scale shows 0.758 , above and over 0.7 cut off threshold (Sekaran \& Bougie), which suggest that the reliability of the scales for measuring credit card spending, bank policies, financial planning, attitude towards money and fresh graduate bankruptcy are considered acceptable (Sekaran \& Bougie, 2010).

\subsection{Demography of Respondents}

Table 1. Gender, age, marital status, occupation, income level, qualification and race

\begin{tabular}{llll}
\hline Types & Categories & Frequency & Percent \\
\hline Gender & Male & 78 & 60 \\
Age & Female & 52 & 40 \\
& 20 years old and below & 12 & 9.2 \\
& 21-30 years old & 100 & 76.9 \\
Marital Status & $31-40$ years old & 12 & 9.2 \\
& 41-50 years old & 6 & 4.6 \\
Occupation & Single & 124 & 95.4 \\
& Married & 6 & 4.6 \\
& Managerial & 11 & 8.5 \\
& Professional & 32 & 24.6 \\
& Business & 13 & 10 \\
& Student & 74 & 56.9 \\
Income Level & Less than 1000 & 55 & 42.5 \\
& 1000-2000 & 54 & 41.5 \\
& 2000-3000 & 13 & 10 \\
& $4000-5000$ & 2 & 1.5 \\
& More than 5000 & 6 & 4.6 \\
& Diploma & 12 & 9.2 \\
& Degree & 118 & 90.8 \\
& Malay & 10 & 7.7 \\
& Chinese & 108 & 83.1 \\
& Indian & 12 & 9.2 \\
\hline
\end{tabular}




\section{Data Analysis}

\subsection{Correlation Analysis}

Table 2. Correlation analysis

\begin{tabular}{|c|c|c|c|c|c|}
\hline & Fresh Graduate & Credit Card & Bank Policies & $\begin{array}{l}\text { Financial } \\
\text { Planning }\end{array}$ & $\begin{array}{l}\text { Attitudes Towards } \\
\text { Money }\end{array}$ \\
\hline Fresh Graduate & 1 & $.951^{* *}$ & $.835^{* *}$ & $.934 * *$ & $.936^{* *}$ \\
\hline \multicolumn{6}{|l|}{ Pearson Correlation } \\
\hline Credit Card & & 1 & $.872 * *$ & $.945^{* *}$ & $.947 * *$ \\
\hline \multicolumn{6}{|l|}{ Pearson Correlation } \\
\hline Bank Policies & & & 1 & $.932 * *$ & $.946^{* *}$ \\
\hline \multicolumn{6}{|l|}{ Pearson Correlation } \\
\hline Financial Planning & & & & 1 & $.974 * *$ \\
\hline \multicolumn{6}{|l|}{ Pearson Correlation } \\
\hline Attitudes Towards Money & & & & & 1 \\
\hline Pearson Correlation & & & & & \\
\hline
\end{tabular}

** Correlations is significant at the 0.01 level (1-tailed).

From table 2, it shows that the relationship between two variables. All of the independent variable is having significant relationship related toward the dependent variable; which is the significant value are lower than $\leq$ 0.05 .

Secondly, under the relationship between fresh graduate bankruptcy and credit card, based from the result, it shows that the fresh graduate bankruptcy has a positive significant relationship with the credit card. Furthermore, Person Correlation was display the strongly relationship between the credit card and factors affect fresh graduate bankruptcy at young age at very high correlation (0.951). In other words, it means that both variables are related.

Thirdly, under the relationship between fresh graduate bankruptcy and bank policies, based from the result, it shows that the strongly relationship between bank policies and factors affect fresh graduate bankruptcy at young age is very high correlation $(0.835)$. It means that bank policies has a very high correlation and related with the factors affect fresh graduate bankruptcy at young age. In other words, it means that both variables are related.

Fourthly, under the relationship between fresh graduate bankruptcy and the financial planning based from the result it shows that the strongly relationship between financial planning and factors affect fresh graduate bankruptcy at young age is very high correlation (0.835). It means both variables are relative connected to each other.

Finally, under the relationship between fresh graduate bankruptcy and the attitude towards money based from the result it shows that the strongly relationship between attitudes towards money and factors affect fresh graduate bankruptcy at young age is very high correlation $(0.936)$. It means both variables are relative connected to each other.

\subsection{Multiple Regression Analysis}

Table 3. Model summary

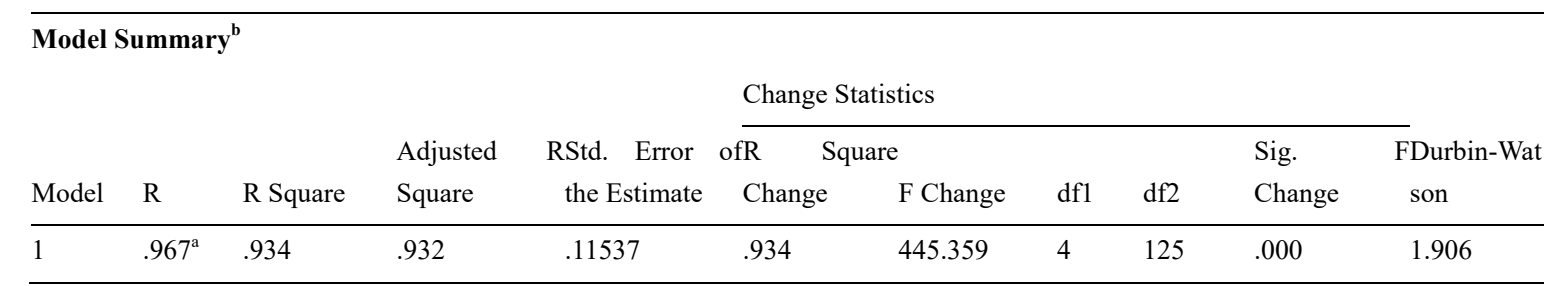

a. Predictors: (Constant), attitudes towards money, bank policies, credit card, financial planning

b. Dependent Variable: Fresh Graduate. 


\subsection{Model Summary}

From the table 3, it shows that the Durbin Watson is 1.906. It indicates that the independent error terms are not correlated. Apart from that, R square also plays an important role in the model summary. The word R here can be defined as the strength of the relationship between the forecast and outcome from this research study measured. Based from the above table, the result shows that the $\mathrm{R}$ square is 0.934 or $93.4 \%$. It also means that $93.4 \%$ of the independent variables like the credit card, bank policies, poor financial planning and attitude towards money can directly affect the dependent variable which is factors affect fresh graduates bankruptcy at young age. At the same time, it also indicates that $93.4 \%$ of the total variance in the dependent variable (factors affect fresh graduates bankruptcy at young age) is explained by the independent variables (credit card, bank policies, poor financial planning and attitude towards money). Hence, the remaining $93.4 \%$ is accounted by other variables which are not involved in this research study.

Table 4. ANOVA ${ }^{\mathrm{a}}$

\begin{tabular}{|c|c|c|c|c|c|c|}
\hline \multicolumn{7}{|c|}{$\mathbf{A N O V A}^{\mathrm{a}}$} \\
\hline & & Sum of Squares & df & Mean Square & $\mathrm{F}$ & Sig. \\
\hline 1 & Residual & 1.664 & 125 & .013 & & \\
\hline
\end{tabular}

a. Dependent Variable: Fresh Graduate.

b. Predictors: (Constant), attitudes towards money, bank policies, credit card, financial planning.

ANOVA table 4 the result shows that the "Sig" column is playing an important role to measure in the ANOVA table. Generally, the ANOVA table is referred at the significant value smaller than 0.05 ; means the "Sig" value should be measured as ( $p$-value $<0.05)$. From the above table, it shows that the "Sig" value is 0.000 which mean $\mathrm{p}$-value $=0.000$. It means that model is fit to use for the further research analysis.

Table 5. Coefficients ${ }^{\mathrm{a}}$

\begin{tabular}{|c|c|c|c|c|c|c|c|c|c|c|}
\hline \multicolumn{11}{|l|}{ Coefficients $^{\mathrm{a}}$} \\
\hline \multirow{3}{*}{ Model } & \multirow{2}{*}{\multicolumn{2}{|c|}{$\begin{array}{l}\text { Unstandardized } \\
\text { Coefficients }\end{array}$}} & \multirow{2}{*}{\multicolumn{3}{|c|}{$\begin{array}{l}\text { Standardized } \\
\text { Coefficients }\end{array}$}} & \multirow{2}{*}{\multicolumn{3}{|c|}{ Correlations }} & \multirow{2}{*}{\multicolumn{2}{|c|}{ Collinearity Statistics }} \\
\hline & & & & & & & & & & \\
\hline & $\mathrm{B}$ & Std. Error & Beta & $\mathrm{t}$ & Sig. & Zero- & erPartial & Part & Tolerance & VIF \\
\hline (Constant) & .327 & .107 & & 3.065 & .003 & & & & & \\
\hline Credit card & .460 & .077 & .464 & 5.943 & .000 & .951 & .469 & .136 & .086 & 11.641 \\
\hline Bank policies & -.408 & .074 & -.409 & -5.487 & .000 & .835 & -.441 & -.126 & .094 & 10.596 \\
\hline $\begin{array}{l}\text { Financial } \\
\text { planning }\end{array}$ & .305 & .107 & .311 & 2.860 & .005 & .934 & .248 & .066 & .044 & 22.612 \\
\hline $\begin{array}{l}\text { Attitudes } \\
\text { towards money }\end{array}$ & .570 & .125 & .580 & 4.547 & .000 & .936 & .377 & .104 & .032 & 31.036 \\
\hline
\end{tabular}

a. Dependent Variable: Fresh Graduate

The "sig" column labels that whether the variables are important or not. Factors affect fresh graduates bankruptcy at young age $=0.327+0.460$ (credit card) +-0.408 (bank policies $)+0.305$ (financial planning) + 0.570 (attitude towards money).

This regression equation is represented that the unit increase in credit card decrease the Factors affect fresh graduates bankruptcy at young age. Moreover, it also shows that the unit increase in bank policies decrease the Factors affect fresh graduates bankruptcy at young age to -0.408. A unit increase in financial planning decrease the Factors affect fresh graduates bankruptcy at young age by 0.305 and a unit increase in attitude towards money decrease the Factors affect fresh graduate's bankruptcy at young age by 0.570 . Hence, there is a negative relationship between both variable based the beta value of unstandardized coefficient. 
According to the table 5, the "Sig" column labels that the entire variables are significant value are $\leq 0.05$. In the table above, it is shown that all the variables are significant because the $\mathrm{p}$ value is less than 0.05 . There are important variables, such as credit card (0.000), bank policies $(0.000)$, financial planning $(0.005)$ and attitude towards money (0.000)

\subsection{Hypotheses Result}

\begin{tabular}{|c|c|c|c|c|}
\hline & Hypothesis & Sig & Result & $\begin{array}{l}\text { Gradient } \\
(\text { Beta, } \beta)\end{array}$ \\
\hline $\mathrm{H}_{1} 1$ & $\begin{array}{l}\text { There will be direct significant and correlation reflect } \\
\text { between the credit card toward the Factors affect fresh } \\
\text { graduates bankruptcy at young age. }\end{array}$ & 0.000 & Supported & 0.460 \\
\hline $\mathrm{H}_{1} 2$ & $\begin{array}{l}\text { There will be direct significant and correlation reflect } \\
\text { between the bank policies toward the Factors affect fresh } \\
\text { graduates bankruptcy at young age. }\end{array}$ & 0.000 & Supported & -0.408 \\
\hline $\mathrm{H}_{1} 3$ & $\begin{array}{l}\text { There will be direct significant and correlation reflect } \\
\text { between the financial planning toward the Factors affect } \\
\text { fresh graduates bankruptcy at young age. }\end{array}$ & 0.000 & Supported & 0.305 \\
\hline
\end{tabular}

\section{Discussion of Findings}

In this following research study, total 130 respondents have participated and have filled in the questionnaires. Most of the respondents that has participated are age range between of 21 years old to 30 years old, respondents consists 2 different gender, occupation type of respondent, income level of respondent and etc. All of the research are conducted with pilot study and turnover reliability test appears to be 0.758 which proof that content of questionnaire is ideal.

\subsection{Result of the Correlation and Multiple Regression Analysis}

These results are coming from 130 respondents and all of the data are compute by IBM SPSS statistics. During the correlation test, factors that affect fresh graduate bankruptcy at young age have been analyzed using Pearson correlation test method. After the test conducted the results show that there is a significant between factors affect fresh graduate bankruptcy at young age with Credit card, bank policies, poor financial planning and attitude towards money.

What comes after the correlation test is the multiple regression analysis, the following results has described using a model summary, ANOVA and a coefficient table. The result shown in Durbin-Watson is 1.906 in the following model summary; it shows that the value is ideal, followed by R Square that is $93.4 \%$ in the model summary, which means the independent variables in the research would affect the dependent variable. Furthermore, ANOVA significant value is 0.000 turns out the results is ideal because it does not exceed more than 0.05 , any amount that is more than 0.05 will not be accepted. Lastly, all of the P-value of independent variable is accepted because it does not exceed 0.05 .

\section{Implication of the Study}

This research studied the factors affect fresh graduate bankruptcy at young age in Selangor. There is 5 independent variable or factors which are credit card, bank policies, poor financial planning and attitude towards money. Fresh graduates at young age will receive information of this study results. Furthermore, they will found out the factors that would affect fresh graduate bankruptcy in Selangor and yet it this information and study will be beneficial to them in the future. In case in future they will be doing research related to this topic, this information will be useful for them as references.

\section{Recommendation for the Future Research}

In the factors of effect fresh graduate bankruptcy at young age, more workloads need to be done. From the information shown in previous section, it shows only 5 independent variables which are credit card, bank policies, poor financial planning and attitude towards money that will influence the dependent variable which is factors affect fresh graduate bankruptcy at young age. 
For future research, therefore, it is advisable to increase the size of the samples due to the fact that more surveys may yield more accurate findings. The future researchers can also use this research as a reference more reliable and useful study in the future.

\section{Conclusion}

Overall, the researcher has discussed about the findings of the analysis that was conducted using the SPSS software. Descriptive approach, correlation and multiple regression analysiss had been shown during the analysis. The descriptive approach displayed direct results while the correlation displayed the relationship between the dependent variable (fresh graduate bankruptcy) and the independent variables (credit card, bank policies, financial planning and attitudes toward money). In addition, the researcher also mentioned the model summary, ANOVA and coefficient table in the multiple regressions. The researcher had also discussed about the implication and limitations of this study. Lastly, the researcher had provided some recommendations for future researchers who will do research of similar topics.

\section{References}

Ahmed, Z. U., Ismail, I., Sadiq Sohail, M., Tabsh, I., \& Alias, H. (2010). Malaysian consumers' credit card usage behavior. Asia Pacific Journal of Marketing and Logistics, 22(4), 528-544. http://dx.doi.org/10.1108/13555851011090547

Allen, M. (2012). Foundations of financial planning: An Overview. Financial Advisor Series.

Alvin, J. W., \& Ben, O. (2015). College student financial capability. International Journal of Bank Marketing, $33(5), 637-653$.

Austin, D. A. (2013). The Indentured Generation: Bankruptcy and Student Loan Debt. Santa Clara Law Review, 53(2), 329-420.

Awanis, S., \& Chi Cui, C. (2014). Consumer susceptibility to credit card misuse and indebtedness. Asia Pacific Journal of Marketing and Logistics, 26(3), 408-429. http://dx.doi.org/10.1108/APJML-09-2013-0110

Awanis, S., \& Chi, C. C. (2014). Consumer susceptibility to credit card misuse and indebtedness. Asia Pacific Journal of Marketing and Logistics, 26(3), 408-429. http://dx.doi.org/10.1108/APJML-09-2013-0110

Blankson, C., Paswan, A., \& Boakye, K. G. (2012). College students' consumption of credit cards. International Journal of Bank Marketing, 30(7), 567-585. http://dx.doi.org/10.1108/02652321211274327

Bynum, C. S. (2016). Relationship between state financial aid and student persistence and success in college.

Devlin, J. F., Worthington, S., \& Gerrard, P. (2007). An analysis of main and subsidiary credit card holding and spending. International Journal of Bank Marketing, 25(2), 89-101. http://dx.doi.org/10.1108/02652320710728429

Dunn, P., \& Liang, C. L. K. (2015). Fallacies versus realities in financial planning and management among entrepreneurs: Lessons from the trenches. Journal of Small Business Strategy, 13(1), 95-104.

Görlich, D., Stepanok, I., \& Al-Hussami, F. (2013). Youth unemployment in Europe and the world: Causes, consequences and solutions (No. 59). Kiel Institute for the World Economy (IfW).

Griffith, W., Paull, K., \& Smith, R. (2015). The Correlation Between Minimum Wage and Youth Unemployment: A Cross Country Analysis.

Grougiou, V., Moschis, G., \& Kapoutsis, I. (2015). Compulsive buying: the role of earlier-in-life events and experiences. Journal of Consumer Marketing, 32(4), 278-289. http://dx.doi.org/10.1108/JCM-01-2015-1283

Hastings, J. S., Madrian, B. C., \& Skimmyhorn, W. L. (2012). Financial literacy, financial education and economic outcomes (No. w18412). National Bureau of Economic Research. http://doi.org/10.3386/w18412

James, J., Hadley Leavell, W., \& Maniam, B. (2002). Financial planning, managers, and college students. Managerial Finance, 28(7), 35-42. http://dx.doi.org/10.1108/03074350210767960

Jill Austin, M., \& Phillips, M. R. (2001). Educating students: an ethics responsibility of credit card companies. Journal of Services Marketing, 15(7), 516-528. http://dx.doi.org/10.1108/EUM0000000006209

Joo Park, E., Young Kim, E., \& Cardona Forney, J. (2006). A structural model of fashion-oriented impulse buying behavior. Journal of Fashion Marketing and Management: An International Journal, 10(4), 433-446. http://dx.doi.org/10.1108/13612020610701965

Joyce, K., Nga, H., Lisa, H. L., Yong, R., \& Sellapan, D. (2010). A study of financial Awareness among youths. 
Young Consumers, 11(4), 277-290.

Lim, H., Heckman, S. J., Montalto, C. P., \& Letkiewicz, J. (2014). Financial stress, self-efficacy, and financial help-seeking behavior of college students. Journal of Financial Counseling and Planning, 25(2), 148-160.

Ludlum, M., Tilker, K., Ritter, D., Cowart, T., Xu, W., \& Smith, B. C. (2012). Financial literacy and credit cards: A multi campus survey. International Journal of Business and Social Science, 3(7).

Ming-Yen Teoh, W., Chong, S. C., \& Mid Yong, S. (2013). Exploring the factors influencing credit card spending behavior among Malaysians. International Journal of Bank Marketing, 31(6), 481-500. http://dx.doi.org/10.1108/IJBM-04-2013-0037

Modesto Veludo-de-Oliveira, T., Augusto Falciano, M., \& Villas Boas Perito, R. (2014). Effects of credit card usage on young Brazilians' compulsive buying. Young Consumers, 15(2), 111-124.http://dx.doi.org/10.1108/YC-06-2013-00382

Moore, R. (2004). Credit card knowledge, attitudes, and practices of college students.

Nga, J. K., \& Ken Yien, L. (2013). The influence of personality trait and demographics on financial decision making among Generation Y. Young Consumers, 14(3), 230-243. http://dx.doi.org/10.1108/YC-11-2012-00325

Noordin, N., Zakaria, Z., Sawal, M. Z. H. M., Ngah, K., \& Hussin, Z. H. (2012). Bankruptcy among young executives in Malaysia. Insight, 28, 132-136.

Pandey, S. K. (2016). The Effect of Deals and Moods on Compulsive Buying: A Study on Young Indian Consumers. Global Business Review. http://doi.org/10.1177/0972150915619821

Park, H. J., \& Davis Burns, L. (2005). Fashion orientation, credit card use, and compulsive buying. Journal of Consumer Marketing, 22(3), 135-141. http://dx.doi.org/10.1108/07363760510595959

Phau, I., \& Woo, C. (2008). Understanding compulsive buying tendencies among young Australians: The roles of money attitude and credit card usage. Marketing Intelligence \& Planning, 26(5), 441-458. http://dx.doi.org/10.1108/02634500810894307

Robb, C. A., \& Sharpe, D. L. (2009). Effect of personal financial knowledge on college students' credit card behavior. Journal of Financial Counseling and Planning, 20(1).

Rose Birch, E., \& Miller, P. W. (2008). The impact of income-contingent provisions on students' loan-taking behaviour. Journal of Economic Studies, 35(1), 4-25. http://dx.doi.org/10.1108/01443580810844406

Segev, S., Shoham, A., \& Gavish, Y. (2015). A closer look into the materialism construct: the antecedents and consequences of materialism and its three facets. Journal of Consumer Marketing, 32(2), 85-98. http://dx.doi.org/10.1108/JCM-07-2014-1082

Shoham, A., \& Makovec, B. M. (2003). Compulsive buying behavior. Journal of Consumer Marketing, 20(2), 127-138. http://dx.doi.org/10.1108/07363760310464596

Sonya, L. B., Anthony, C., Fred, F., Kristen, S., \& Racquel, T. (2015). Financial Stress, and financial Counseling: Helping college students. Journal Of Financial Counselling and Planning, 26(2), 172-186.

Vleugels, W., Rothmann, S., Griep, Y., \& De Witte, H. (2013). Does financial hardship explain differences between Belgian and South African unemployed regarding experiences of unemployment, employment commitment, and job search behaviour? Psychologica Belgica, 53(2). http://doi.org/10.5334/pb-53-2-75

Warwick, J., \& Mansfield, P. (2000). Credit card consumers: college students' knowledge and attitude. Journal of Consumer Marketing, 17(7), 617-626. http://dx.doi.org/10.1108/07363760010357813

\section{Copyrights}

Copyright for this article is retained by the author(s), with first publication rights granted to the journal.

This is an open-access article distributed under the terms and conditions of the Creative Commons Attribution license (http://creativecommons.org/licenses/by/4.0/). 